\title{
At the Intersection of the Pathways for Exocytosis and Autophagy
}

\author{
D.A. Brooks, C. Bader, Y.S. Ng, \\ R.D. Brooks, G.N. Borlace and T. Shandala \\ Mechanisms in Cell Biology and Diseases Research Group, \\ School of Pharmacy and Medical Sciences, Sansom Institute for Health Research \\ University of South Australia \\ Australia
}

\section{Introduction}

Recent studies have suggested that there are molecular links between the two critical biological processes of exocytosis and autophagy. Exocytosis involves the transport of intracellular vesicles to the plasma membrane of the cell, where vesicular fusion results in the delivery of membrane and protein to the cell surface, and secretion of the vesicular contents. Exocytosis is utilized in, for example, hormone or antimicrobial peptide secretion, the delivery of proteoglycans to the cell surface, cell-cell communication and neurotransmission (Brennwald \& Rossi, 2007; He \& Guo, 2009). Autophagy is a mechanism for the recycling and degradation of cytoplasmic content, which involves surrounding an area of cytoplasm with a double membrane structure, which then interacts with degradative endosome-lysosome compartments (He \& Klionsky, 2009). Autophagy has important functions in a range of cell processes including the maintenance of cellular homeostasis, starvation adaption, energy balance, organelle clearance, immunity and cell death. In human diseases, such as cancers, neurodegenerative disorders (e.g. Huntington's disease), and chronic inflammatory diseases (e.g. Crohn's disease), there have been reports of functional disparity in both of these important membrane-related cellular pathways. There is now increasing evidence that exocytosis and autophagy share molecular machinery and there are a number of reasons why this would be beneficial in terms of cellular function.

Exocytosis and autophagy may be competitively, cooperatively or independently regulated, depending upon the nature of the intracellular and/or extracellular environment. In response to conditions of low or high energy demand, there would be an advantage to the cell in reducing the energy consuming process of secretion, where the membrane from exocytic vesicles could be utilized to enable rapid expansion of the autophagic compartment (i.e. competitive regulation). During an immune response there may be concomitant stimulation of autophagy to degrade an intracellular bacterial pathogen, and exocytosis to release second messengers and antimicrobial effectors. Alternatively, it may be necessary to only upregulate an individual process, which is the case for increased autophagy during organelle and cytoplasm turnover under restricted nutrient supply (e.g. in the bone growth plate) (He \& Klionsky, 2009), or increased exocytosis during proteoglycan delivery to the 
cell surface (Franken et al., 2003). Finally, during the removal of dysfunctional exocytic vesicles or the rapid cessation of secretion (e.g. during neurotransmission), the cell requires organelle-specific molecular machinery, for the nucleation of autophagy (Geng et al., 2010).

Despite defects in multiple human syndromes that demonstrate changes in both exocytosis and autophagy, the mutual dependence of these processes on common molecular machinery has only recently been investigated. Evidence indicates that the exocyst complex and its regulator Ral (Ras like GTPase), both of which are known to have a critical function in exocytosis, also appear to be essential for the initiation of autophagy (Bodemann et al., 2011). Similarly, the small GTPase Rab11 has a critical role in exocytosis at the recycling endosome and in exocytic vesicle function (van Ijzendoorn, 2006), although in times of starvation where autophagy is induced, Rab11 containing vesicular compartments have been shown to asscociate with autophagosomes (Rab11 positive amphisomes; (Fader et al., 2008)). Finally, disruption of the exocytic Rab GTPase Sec4 and its guanine nucleotide exchange factor Sec2, can have significant effects on the anterograde movement of the integral autophagosome membrane protein Atg9 (Autophagy related protein 9), thereby influencing the recruitment of Atg8 to the phagophore assembly site (PAS) (Bodemann et al., 2011). The movements of Atg9 and Atg8 are of particular interest as they are both important during the initiation of autophagy (Geng et al., 2010; Wang et al., 2009). Atg9 has, in turn, been reported to reside on exocytic vesicles that can be converted into a phagophore assembly site (Mari et al., 2010; Mari \& Reggiori, 2010). The aim of this chapter is to provide an overview of the exocytic and autophagic processes with a focus on the common molecular machinery acting at critical control points. It is this machinery that may facilitate communication between these functionally distinct vesicular compartments and may act as potential sites for regulation.

\section{Exocytosis}

The exocytic pathway delivers cargo carrying vesicles from either the trans-Golgi network (TGN) or recycling endosomes to the plasma membrane, where membrane fusion occurs to release the vesicular content (Figure 1). This vesicular content may be either vesicle membrane proteins directed to the cell surface, or lumenal contents for secretion into the extracellular milieu. This anterograde trafficking route may vary depending upon the cargo and cell type involved (Wurster et al., 1990), such as in melanocytes for melanin exocytosis and in neurons for neurotransmission. Exocytosis is also involved in numerous other cellular functions, including immune responses, cell-cell communication, cell growth, cell polarity and neurotransmission.

There are two main exocytic routes from the trans-Golgi network to the plasma membrane: the constitutive and the regulated routes (Stow et al., 2009). The constitutive route continuously delivers membrane and cargo from the trans-Golgi network to the cell surface, and is thought to be utilized for housekeeping functions. Although this process can be upregulated in response to environmental stress, it is generally representative of a basal level of cell activity and secretion. However, a number of pro-inflammatory cytokines, including $\mathrm{TNF} \alpha$ and IL-6, are released from macrophages via the constitutive route, in response to pro-inflammatory stimuli (Shurety et al., 2000). The regulated route involves the redirection of newly synthesized cargo to compartments where these molecules are stored until their release is triggered by a specific stimulus (mediated by calcium ion mobilization). In this 


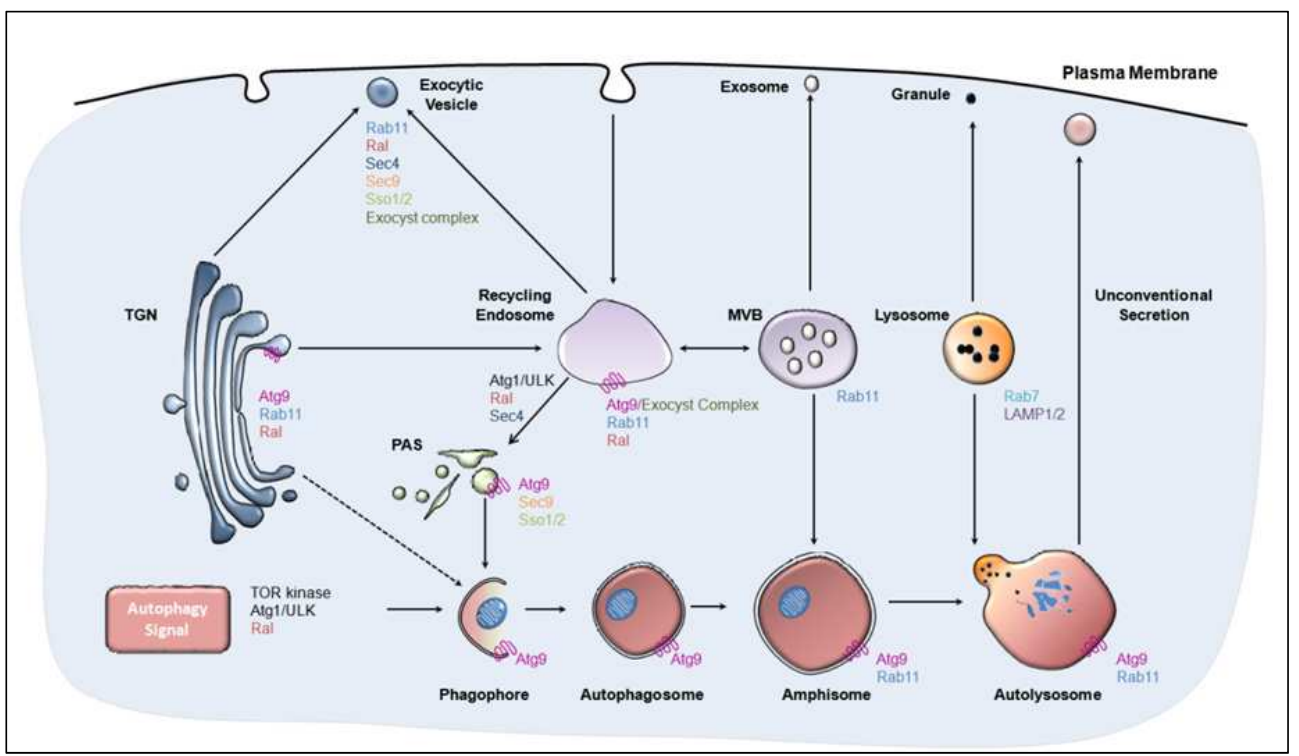

Fig. 1. Proposed model for crosstalk between autophagy and exocytosis.

route, cargo can be trafficked via a number of compartments including recycling endosomes, early endosomes, multivesicular bodies, secretory granules and secretory lysosomes. This pathway is utilized for the immune related secretion of cytokines and antimicrobial peptides, following exposure to pathogens or inflammatory stimuli. Similarly, for neurotransmitter release, exocytosis is stimulated by an increase in the intracellular calcium ion concentration in neurons; which allows the propagation of neuronal function. These different pathways are in dynamic balance with the endocytic pathway, which, apart from facilitating uptake into the cell, allows the recovery of membrane from the plasma membrane following exocytosis, enabling the cell to control its surface area (Khandelwal et al., 2010). The molecular machinery that drives exocytosis therefore operates in conjunction with the endocytic machinery, and in some cases may involve common elements that have dual function.

\subsection{The molecular machinery for exocytosis}

The molecular machinery that facilitates the process of exocytosis can vary with respect to the specific cell type and specialist cargo being transported, although two key molecular complexes are conserved for most membrane associated exocytic events; the exocyst and the soluble N-ethylmaleimide sensitive factor attachment protein receptor (SNARE) complex (Liu \& Guo, 2011; Nair et al., 2011). Through interaction with a number of effector molecules, these complexes mediate the tethering, docking and fusion of vesicles with the plasma membrane.

The exocyst is an octomeric complex that is required for the efficient delivery of exocytic vesicles to the plasma membrane (TerBush et al., 1996). The components of the exocyst complex were first identified for yeast in the early 1990's, with mammalian orthologues 
subsequently being identified (Lipschutz \& Mostov, 2002). In yeast, this complex consists of six secretion related proteins (Sec), Sec3, Sec5, Sec6, Sec8, Sec10 and Sec15, with an additional two subunits known as exocyst related proteins (Exo), Exo70 and Exo84. Tethering to the plasma membrane is mediated by GTPase proteins, such as the yeast proteins, Rho3 and Cdc42 (He et al., 2007; He \& Guo, 2009), or by TC10 in mammalian cells (Dupraz et al., 2009; Inoue et al., 2006; Pommereit \& Wouters, 2007). Recognition of the exocytic vesicle by the exocyst is mediated by the Rab GTPase proteins, Sec4 in yeast (Guo et al., 1999; Zajac et al., 2005) or Rab11 in metazoans (Novick \& Guo, 2002; Novick et al., 2006). In mammalian cells, assembly of this complex is controlled by RalA and RalB (Chen et al., 2011a; Chen et al., 2007; Chen et al., 2011b).

Assembly of the exocyst serves to tether exocytic vesicles to a specific plasma membrane site, demarcated by phosphatidylinositol 4,5-bisphosphate (PI $(4,5) \mathrm{P} 2)$, Sec3 and Exo70 (He et al., 2007; He \& Guo, 2009). The Sec3 and Exo70 membrane associated components of the exocyst act to target vesicles to the site of exocytosis, via the direct association of positively charged residues in the $\mathrm{D}$ domain at the C-terminus with $\mathrm{PI}(4,5) \mathrm{P} 2$, in the plasma membrane (He et al., 2007; He \& Guo, 2009). Multiple GTPases then regulate the assembly interface of a full octameric exocyst complex. The GTPase proteins Rho3 and Cdc42 also interact with Exo70 and Sec3 to facilitate the assembly of the exocyst complex at the plasma membrane (He et al., 2007; Moskalenko et al., 2002). In mammalian cells, Exo70 facilitates exocyst association with the plasma membrane through its interaction with TC10 (the orthologue of Cdc42) (Inoue et al., 2003; Liu et al., 2007). In yeast, secretory vesicles acquire the Rab GTPase protein Sec4, which directly interacts with the exocyst, via the Sec15 subunit, thus allowing the secretory vesicle to be recognised by the exocyst plasma membrane complex. Unlike in yeast, the vesicular targeting of the exocyst in metazoans is thought to occur through interactions between Sec15 and Rab11 (Langevin et al., 2005; Wu et al., 2005; Zhang et al., 2004), and the tethering of the secretory vesicles to the plasma membrane is regulated by Sec5 and Ral (Brymora et al., 2001; Chen et al., 2011a; Li et al., 2007). Active RalA (GTP bound form) interacts with Sec5, and upon delivery of the vesicles to the plasma membrane, the interaction between RalA-Sec5 is broken through the phosphorylation of Sec5 by protein kinase C (PKC) (Chen et al., 2011a). Detachment of Sec5 from RalA allows the release of the exocyst complex once the vesicle is delivered to the plasma membrane. The emerging model for the assembly of the exocyst suggests that the components are present as distinct sub-complexes on vesicles and the plasma membrane. In this manner, the assembly of the exocyst may integrate various cellular signalling pathways to ensure that exocytosis is tightly controlled (Sugihara et al., 2002).

Following cell surface membrane tethering by the exocyst complex, SNARE proteins facilitate the final step of exocytosis by bringing together the vesicular and plasma membranes for fusion. There are two groups of SNARE proteins; t-SNAREs, such as syntaxin1 and Sec9, which are found on the inner leaflet of the plasma membrane of cells and denote the target membrane; and v-SNAREs, which are found on a range of membrane compartments and denotes the vesicular membrane (Shorer et al., 2005; Stow et al., 2006). These proteins work by cognate pairing of t-SNAREs with their opposing v-SNAREs to form a four helix bundle, which allows the two membranes to be brought into close proximity, and this facilitates membrane fusion (Stow et al., 2006). A number of studies have 
provided evidence of interactions between SNARE proteins and components of the exocyst complex (Bao et al., 2008; Hattendorf et al., 2007; Wiederkehr et al., 2004; Zhang et al., 2005). In yeast, this interaction is orchestrated though WD-40 adaptor proteins Sro7p and Sro77p (Zhang et al., 2005), which are homologues of lethal giant larvae (Lgl); first identified as a tumor suppressor in Drosophila (Gateff, 1978) and since demonstrated to play a role in cell polarity (Bilder et al., 2000). Sro7p and Sro77p interact with the exocyst components Sec6 and Exo84 as well as t-SNARE Sec9, thus providing a link between these two complexes to mediate the final steps of membrane fusion and exocytosis (Zhang et al., 2005).

\section{Autophagy}

Autophagy is responsible for a number of routine housekeeping functions, including the elimination of defective proteins, the prevention of abnormal protein aggregate accumulation, the turnover of glycogen, the removal of intracellular pathogens and the recycling of aged or dysfunctional organelles. These functions are likely to be critical for autophagy-mediated protection against aging, cancer, neurodegenerative disease and infection (Levine \& Kroemer, 2008). Autophagy involves the engulfing of cytoplasmic content into a double membrane vesicle, which is used to mediate the degradation of the internalised contents following interaction with endosome and lysosome compartments (Figure 1). Autophagy normally occurs at a basal level, but stimuli such as starvation, hormonal and developmental signals, accumulation of unfolded proteins or invasion of microorganisms, can each modulate the rate of autophagic activity (Meijer \& Codogno, 2004).

\subsection{The induction and sequence of the autophagic process}

The process of autophagy is mediated by the recruitment of autophagy related proteins to the limiting membranes of the forming phagosome, where they assemble the so-called preautophagosomal structure. This nucleation step is known to occur at sites adjacent to mitochondria in yeast (Mari \& Reggiori, 2010), while other eukaryotes are thought to have multiple nucleation sites that may include the endoplasmic reticulum, Golgi, mitochondria and secretory vesicles (Hailey et al., 2010; Hamasaki \& Yoshimori, 2010; Militello \& Colombo, 2011; Tooze \& Yoshimori, 2010; Weidberg et al., 2011). Autophagosomes are formed via the expansion of the isolation membrane to completely surround an area of cytoplasm. Maturation of the autophagosome involves fusion with a multivesicular body to form an amphisome, which subsequently fuses with a lysosome to become a fully functional autolysosome. Through the action of lysosomal enzymes, the degradation process then recycles molecular constituents back into the cytoplasm.

\subsection{The molecular machinery involved in autophagosome formation and maturation}

The induction and nucleation of autophagy is dependent on the successive assembly of a number of complexes within the cytoplasm, such as the Atg1-Atg13 (or mammalian unc-51like kinase 1(Ulk1)-Atg13) kinase complex and the Atg5-Atg12 ubiquitin-like conjugation system. Up-stream signalling pathways lead to the activation of the Atg1/Ulk1 complex, which in turn recruits other members of the autophagic machinery to the site of nucleation. The exact mode for this recruitment is as yet unknown, however the individual step-specific complexes are well described for yeast and higher eukaryote systems. 
One of the upstream regulators, targets of rapamycin (TOR) acts as an inhibitor of autophagy. Inactivation of TOR leads to the assembly of an active Atg1 complex; Atg1:Atg13:Atg17 in yeast (Kamada et al., 2000; Nakatogawa et al., 2009), and Ulk1:Atg13:FIP200 in higher eukaryotes (Chang \& Neufeld, 2010; Mehrpour et al., 2010). In the latter case, activation is thought to occur via a change in Atg13-mediated phosphorylation of Ulk1 (Chang \& Neufeld, 2010), although the exact site and the induction signal for this initiation step remains unclear (Chang \& Neufeld, 2009, 2010; Mehrpour et al., 2010).

The solution to the mystery of the origin of autophagic compartment may lay in the biology of Atg9, the only trans-membrane autophagic protein that is present throughout autophagosome maturation. In yeast, Atg9 has been observed to form clusters near the mitochondria, suggesting the possibility of a membrane pool for autophagy (Mari \& Reggiori, 2010). However, an equivalent structure has yet to be identified in other eukaryotes, and there may be multiple nucleation sites, including the endoplasmic reticulum, Golgi, mitochondria (Hailey et al., 2010; Hamasaki \& Yoshimori, 2010; Tooze \& Yoshimori, 2010) and plasma membrane (Ravikumar et al., 2010). Recent studies in mammalian cells showed that Atg9 initially resides at the Golgi and is trafficked to recycling endosomes (Wang et al., 2011; Webber et al., 2007; Webber \& Tooze, 2010). This suggests the involvement of the Golgi complex in the autophagic pathway. Starvation dependent trafficking of mammalian Atg9 to the pre-autophagosomal structure requires the Atg1/Ulk1 kinase, Atg13, as well as p38 MAPK interaction protein, p38IP (Webber \& Tooze, 2010). Following Atg9 recruitment, nucleation of the pre-autophagosomal structure limiting membrane is controlled by a protein complex containing a member of the vacuolar protein sorting family, Vps34, and Atg6/Beclin1. Atg6 is crucial for the recruitment of other autophagic proteins to the pre-autophagosomal structure, while Vps34 kinase phosphorylates phosphatidylinositol $\left(\mathrm{PI}_{3} \mathrm{P}\right)$ in order to recruit Atg8 and Atg18 (Kundu \& Thompson, 2008; Polson et al., 2010).

Two ubiquitin-like conjugation systems are required for the expansion and closure of the autophagosome, Atg5-Atg12 and the Atg8-phosphotidylethanolamine complex (Ichimura et al., 2000; Mizushima et al., 1998). In the first of these systems the conjugated form of Atg5Atg12 associates with Atg16 dimers to become a multimeric Atg5-Atg12-Atg16 complex. It is believed that this Atg5-Atg12-Atg16 complex is required for the formation of preautophagosomal structures, and allows association with the second Atg8 related conjugation system. In the second ubiquitin-like conjugation system, cytosolic Atg8, or LC3 (microtubule-associated protein 1 light chain 3 ) in mammals, is modified by the attachment of the phospholipid anchor phosphatidylethanolamine, or PE. This step results in the localisation of Atg8/LC3-PE to the isolation membrane of the phagophore and may contribute to the expansion of autophagic membranes (McPhee \& Baehrecke, 2009; Nakatogawa et al., 2007).

Once the autophagosome is closed by fusion of the expanding edges of the phagophore, its maturation proceeds through fusion with multi-vesicular bodies, late endosomes and lysosomes (Razi et al., 2009). It has been suggested that fusion of the autophagosome with endocytic compartments is facilitated by endosome membrane fusion machinery (Eskelinen, 2005) including the membrane targeting proteins Rab11 and Rab7 GTPases and membrane fusion protein complexes, such as SNAREs, ESCRT proteins, Vps28, Vps25, Vps32, Deep 
Orange (Dor)/Vps18 and Carnation (Car)/Vps33a (Fader et al., 2008; Gutierrez et al., 2004a; Gutierrez et al., 2004b; Simonsen \& Tooze, 2009), as well as the lysosomal membrane proteins, Lamp-1 and Lamp-2 (Tanaka et al., 2000). After fusion with the lysosome, degradation of protein, lipid, glycogen, RNA, DNA and other contents is dependent upon the action of lysosomal acid hydrolases (Koike et al., 2005; Tanaka et al., 2000; Tanida et al., 2005). The small molecules (e.g. amino acids and sugars) are then transported back to the cytosol for protein synthesis and the maintenance of other cellular functions (He \& Klionsky, 2009).

\section{Diseases that show links between exocytosis and autophagy}

Altered regulation of exocytosis and autophagy has been shown in a number of debilitating diseases including cancer (Gozuacik \& Kimchi, 2006; Levine, 2007; Miracco et al., 2007; Pattingre et al., 2005; Tayeb et al., 2005), neurodegenerative diseases (Gao \& Hong, 2008; Keating, 2008; Yu et al., 2005), and chronic inflammatory diseases (Barbier, 2003; Barrett, 2008; Cadwell et al., 2010; Fujita et al., 2008; Homer et al., 2010; Rioux, 2007; Saitoh et al., 2008).

In cancer, the uncontrolled cell proliferation that results in tumor outgrowth is associated with increased secretion of pro-oncogenic proteins and lysosomal enzymes. Thus, lysosomal cathepsins, acid phosphatase and various glycosidases have been used as diagnostic markers and to define metastatic potential in a range of cancers (Tappel, 2005). The underlying reason for this increase in lysosomal enzyme secretion may be linked to the increase in endosome-lysosome membrane recycling that is required to maintain plasma membrane area during rapid cell division (Boucrot \& Kirchhausen, 2007). Increased lysosomal enzyme secretion has also been associated with extracellular matrix degradation and this can facilitate metastasis (Tayeb et al., 2005). The migration of metastatic cancer cells also involves upregulated exocytosis, as a means of membrane delivery to the leading edge of the migrating cell. This allows the formation of lamellipodia and filopodia, and thereby cellular movement. Exocytosis and cell division are both high energy demand cellular processes, and so it is not too surprising that autophagy has also been implicated in the carcinogenic process, as a means of energy supply.

There is, however, controversy in the literature regarding the pro-survival and pro-death functions of autophagy (Hippert et al., 2006; Kundu \& Thompson, 2008; Levine, 2007; Levine \& Kroemer, 2008). The cyto-protective role that autophagy has under conditions of starvation or low energy supply, prevents apoptosis (Boya et al., 2005), and is therefore thought to promote cancer cell growth and survival within solid tumors prior to vascularization. In stark contrast, the suppression of autophagy via a number of regulatory pathways can lead to tumorigenesis (Gozuacik \& Kimchi, 2006; Levine, 2007; Miracco et al., 2007; Pattingre et al., 2005). The increased tumorigenesis observed in beclin1/Atg6 and Atg5 murine mutants, and the high number of mono-allelic deletion mutations in these genes observed in different types of human cancer, indicate a direct tumor suppressor role for autophagy (Aita et al., 1999; Hippert et al., 2006; Kundu \& Thompson, 2008; Levine, 2007). In addition, p53 and PTEN, which are frequently mutated in cancer patients, can stimulate autophagy (Bae et al., 2007; Lindmo et al., 2006; Shin et al., 2011; Wang et al., 2011); while PI3K, p38 MAPK and Akt, which are often activated in cancer, can suppress autophagy (Webber \& Tooze, 2010). The apparent disparate roles of autophagy in cancer make it difficult to ascertain its exact function, and it also remains unclear whether exocytosis and autophagy are acting independently or as inter-linked 
processes in this disease. However, in one study, the trafficking of lysosomes in cancer cells was found to be linked to autophagosome formation through the common molecular machinery of the microtubule -dependent motor protein KIF5B (kinesin heavy chain protein 5B; Cardoso et al., 2009) a protein previously demonstrated to be involved in exocytosis (Varadi et al., 2002).

Neurodegenerative disorders including Parkinson's, Huntington's and Alzheimer's disease are progressive disorders, which have in common the loss of function of neurons in discrete areas of the central nervous system. This loss of function is thought to be a result of aggregation of misfolded proteins. Autophagy has a role in the degradation of misfolded protein (Yu et al., 2005), and the functional loss of Atg5 or Atg7 results in the accumulation of ubiquitinated protein aggregates, and a neurodegenerative phenotype (Hara, 2006; Komatsu et al., 2006). Furthermore, altered autophagy has been shown to be linked with altered exocytosis in a number of neurodegenerative disorders, leading to impaired release of neurotransmitters and increased inflammation (Gao \& Hong, 2008; Keating, 2008). This highlights a direct link between autophagy and the recycling of the specialist secretory vesicles that control neurotransmission at the synaptic terminals of neurons.

Some inflammatory diseases, such as Crohn's disease, are thought to be caused by a breakdown in the regulation of exocytosis leading to increased secretion of proinflammatory factors (Barbier, 2003; Cadwell et al., 2010). In addition, a number of genetic screens of patients suffering from Crohn's disease have identified mutations in autophagy related genes (Barrett, 2008; Rioux, 2007). The autophagy related protein Atg16L is thought to function as a scaffold for LC3 lipidation, by dynamically localizing to the source of membrane involved in autophagosome formation (Fujita et al., 2008). A genetic defect in Atg16L may decrease the efficiency by which pathogens can be cleared from cells via autophagy, evoking an increased inflammatory response (Fujita et al., 2008; Homer et al., 2010; Saitoh et al., 2008). In addition, there is mounting evidence that defects in this autophagy gene can also lead to defects in exocytosis, causing a build-up of secretory granules in specific cell types (Cadwell et al., 2009). These concurrent defects in both exocytosis and autophagy may be one more piece of evidence for co-regulation and a shared molecular link between these two cellular processes, and raises the important question: is there common molecular machinery for exocytosis and autophagy?

\section{Exocytosis and autophagy: Common cellular functions and molecular machinery}

Exocytosis and autophagy are essential for a number of common biological processes, including; the immune response (Govind, 2008; Minty et al., 1983; Murray et al., 1998; Ostenson et al., 2006), cell growth (Brennwald \& Rossi, 2007; Orlando \& Guo, 2009; Wei \& Zheng, 2011; Zhang et al., 2005), cell proliferation and apoptosis (Kundu, 2011; Shin et al., 2011; Zeng et al., 2012), and multicellular organism development (Gutnick et al., 2011; Hu et al., 2011; Sato \& Sato, 2011; Tra et al., 2011). Autophagy and exocytosis both involve membrane trafficking and fusion events and so similar groups of molecular machinery may be required for both processes: such as GTPase proteins, that facilitate membrane tethering and SNARE proteins which are involved in membrane fusion. There is increasing evidence indicating shared molecular machinery between these processes, which provokes questions concerning possible dual regulation as a means of balance for these pathways. 
Autophagy and exocytosis can have opposing or synergistic roles in cell function. For example, during times of reduced nutrient availability autophagy is stimulated, allowing cells to recycle cytoplasmic components, and exocytosis is reduced to conserve cellular constituents and energy (Shorer et al., 2005). In response to stimulation, specialised secretory cells (e.g. chromaffin neuroendicrine cells) divert energy utilization towards the exocytic pathway (Malacombe et al., 2006). Conversely, when a cell is presented with an immune challenge, both exocytosis and autophagy can be upregulated; exocytosis for the release of immune response factors and autophagy to clear invading pathogens from cells (Stow et al., 2009). Given these findings, it would appear to be of advantage to cells to have a mechanism coordinating the activity of these two processes.

\subsection{The endosomal network is involved in both exocytosis and autophagy}

The dynamic flow of membrane and membrane proteins within a cell is mediated through the endosomal network (Figure 1). For example, lipids and proteins from the plasma membrane are recovered by the cell for cytosolic recycling via compensatory endocytosis, which also allows for the maintenance of membrane homeostasis at the sites of active exocytosis; directing endocytosed membrane back into the endosomal network or Golgi for degradation or recycling (Sramkova et al., 2009). This type of endocytosis is of particular importance in specialized secretory cells, such as, bladder umbrella cells (Khandelwal et al., 2008; Khandelwal et al., 2010), neurons (Kim \& von Gersdorff, 2009; Llobet et al., 2011; Logiudice et al., 2009) and neuroendocrine cells (Engisch \& Nowycky, 1998; Barg \& Machado, 2008). This allows for the rapid recycling of secretory vesicles back into the reserve pool. Endosomes are at the nexus of the exocytic and autophagic pathways allowing for the sorting and directing of membrane. Thus, in yeast, Atg9 clusters are connected with both the endocytic and exocytic systems, and delivered to the phagophore assembly site via recycling endosomes (Geng et al., 2010; Mari et al., 2010). The recycling endosome's exocytic function is involved in the maintenance of cell polarity through the sorting of membrane proteins such as clathrin and cadherin (Farr et al., 2009). The recycling endosome machinery also plays a role in the fusion of multivesicular bodies with autophagosomes, which is an essential step in phagosome maturation (Fader \& Colombo, 2009; Razi et al., 2009; Tooze \& Razi, 2009). Recent studies have suggested a significant overlap of the molecular machinery used in these two biological processes (Bodemann et al., 2011; Geng et al., 2010). This involves the exocyst complex and its regulators (e.g. small GTPases), as well as membrane fusion machinery (e.g. SNAREs; Table 1).

\subsection{Small GTPases at the cross road of exocytosis and autophagy}

\subsubsection{Ral small GTPase}

Ras-like proteins (Ral) are small GTPases that function as an essential component of the cellular machinery regulating the post-Golgi targeting of exocytic vesicles to the plasma membrane (Balasubramanian et al., 2010; Chen et al., 2007; Kawato et al., 2008; Kim et al., 2010; Ljubicic et al., 2009; Lopez et al., 2008; Rondaij et al., 2008; Rosse et al., 2006; Shipitsin \& Feig, 2004; Spiczka \& Yeaman, 2008). Ral function is directly mediated by its interaction with the exocyst complex (Feig, 2003; Kawato et al., 2008; Mark et al., 1996; Mott et al., 2003), in particular Sec5 which has been shown to be essential for Ral-exocyst dependent exocytosis (Fukai et al., 2003; Moskalenko et al., 2002). 


\begin{tabular}{|c|c|c|c|c|}
\hline Protein & Role in Exocytosis & References & Role in Autophagy & References \\
\hline Ral & \begin{tabular}{|l|} 
Interacts with \\
exocyst via Sec5 to \\
facilitate the \\
tethering of \\
vesicles to the \\
plasma membrane.
\end{tabular} & $\begin{array}{l}\text { (Balasubramanian et al., 2010; } \\
\text { Brymora et al., 2001; Chen et al., } \\
\text { 2011a; Chen et al., 2007; Fukai et } \\
\text { al., 2003; Kawato } \text { et al., 2008; Li et } \\
\text { al., 2007; Ljubicic et al., 2009; } \\
\text { Lopez et al., 2008; Mark et al., } \\
\text { 1996; Moskalenko et al., 2002; } \\
\text { Mott et al., 2003; Shipitsin \& Feig, } \\
\text { 2004) }\end{array}$ & \begin{tabular}{|l|} 
RalB but not RalA \\
involved in initation \\
of autophagy in \\
mammalian cell \\
lines. Over \\
expression of active \\
RalB enhances \\
autophagy while \\
depletion decreases \\
autophagy.
\end{tabular} & $\begin{array}{l}\text { (Bodemann } \\
\text { et al., 2011) }\end{array}$ \\
\hline Rab11 & $\begin{array}{l}\text { Bound to exocytic } \\
\text { vesicles and is } \\
\text { involved in the } \\
\text { anterograde } \\
\text { trafficking of } \\
\text { vesicles from } \\
\text { recycling } \\
\text { endosomes to the } \\
\text { plasma membrane. } \\
\text { Interacts with the } \\
\text { exocyst } \\
\text { component Sec15 } \\
\text { to assist tethering } \\
\text { of vesicles to the } \\
\text { plasma membrane. }\end{array}$ & $\begin{array}{l}\text { (Langevin et al., 2005; Oztan et } \\
\text { al., 2007; Shandala et al., 2011; } \\
\text { Ward et al., 2005; Wu et al., 2005; } \\
\text { Zhang et al., 2004) }\end{array}$ & \begin{tabular}{|l|} 
Facilitates fusion of \\
the autophagosome \\
with endocytic \\
compartments.
\end{tabular} & $\begin{array}{l}\text { (Fader et al., } \\
2008)\end{array}$ \\
\hline Sec4 & \begin{tabular}{|l|} 
Allows the \\
interaction of the \\
secretory vesicle \\
with the exocyst \\
complex via Sec15 \\
to facilitate \\
tethering to the \\
plasma membrane.
\end{tabular} & (Guo et al., 1999) & \begin{tabular}{|l|} 
Involved in the \\
recruitment of Atg9 \\
to the PAS.
\end{tabular} & $\begin{array}{l}\text { (Geng et al., } \\
2010)\end{array}$ \\
\hline \begin{tabular}{|l|} 
Exocyst \\
Complex
\end{tabular} & $\begin{array}{l}\text { Octomeric } \\
\text { complex required } \\
\text { for tethering of } \\
\text { exocytic vesicles to } \\
\text { the plasma } \\
\text { membrane in a site } \\
\text { specific manner }\end{array}$ & $\begin{array}{l}\text { (He et al., 2007; He \& Guo, 2009; } \\
\text { Jin et al., 2011; Langevin et al., } \\
\text { 2005; Morgera et al., 2012) }\end{array}$ & $\begin{array}{l}\text { Proposed as a } \\
\text { scaffold for the } \\
\text { initiation of } \\
\text { autophagy } \\
\text { complexes. }\end{array}$ & $\begin{array}{l}\text { (Bodemann } \\
\text { et al., 2011; } \\
\text { Farré \& } \\
\text { Subramani, } \\
\text { 2011) }\end{array}$ \\
\hline Sso1/2-Sec9 & $\begin{array}{l}\text { t-SNARE that } \\
\text { denotes the site of } \\
\text { exocytosis on the } \\
\text { plasma membrane, } \\
\text { possibly through } \\
\text { interactions with } \\
\text { the exocyst } \\
\text { complex and its } \\
\text { effectors }\end{array}$ & $\begin{array}{l}\text { (Aalto et al., 1993; Brennwald et } \\
\text { al., 1994) }\end{array}$ & \begin{tabular}{|l|} 
Involved in the \\
formation of Atg9 \\
associated tubule- \\
vesicular clusters \\
emanating from the \\
PAS
\end{tabular} & $\begin{array}{l}\text { (Nair et al., } \\
\text { 2011) }\end{array}$ \\
\hline
\end{tabular}




\begin{tabular}{|c|c|c|c|c|}
\hline Protein & Role in Exocytosis & References & Role in Autophagy & References \\
\hline VAMP7 & $\begin{array}{l}\text { Involved in } \\
\text { constitutive } \\
\text { exocytosis in a } \\
\text { number of cell } \\
\text { types }\end{array}$ & $\begin{array}{l}\text { (Galli et al., 1998; Oishi et al., } \\
\text { 2006) }\end{array}$ & $\begin{array}{l}\text { Involved in } \\
\text { lysosome fusion } \\
\text { during } \\
\text { autophagosome } \\
\text { maturation }\end{array}$ & $\begin{array}{l}\text { (Fader et al., } \\
\text { 2009) }\end{array}$ \\
\hline Atg9 & $\begin{array}{l}\text { Unknown role but } \\
\text { has been found on } \\
\text { secretory vesicles. } \\
\text { May have a role in } \\
\text { unconventional } \\
\text { secretion }\end{array}$ & $\begin{array}{l}\text { (Bruns et al., 2011; Mari et al., } \\
\text { 2010) }\end{array}$ & $\begin{array}{l}\text { Transmembrane } \\
\text { protein required for } \\
\text { the transport and } \\
\text { assembly of } \\
\text { membrane during } \\
\text { autophagosome } \\
\text { formation }\end{array}$ & $\begin{array}{l}\text { (He et al., } \\
2009)\end{array}$ \\
\hline Atg16L & \begin{tabular}{|l|} 
Involved in \\
secretion from \\
secretory granules \\
in intestinal \\
Paneth cells
\end{tabular} & $\begin{array}{l}\text { (Cadwell et al., 2008; Cadwell et } \\
\text { al., 2009) }\end{array}$ & $\begin{array}{l}\text { Functions as a } \\
\text { scaffold for LC3 } \\
\text { lipidation, required } \\
\text { during } \\
\text { autophagosome } \\
\text { formation }\end{array}$ & $\begin{array}{l}\text { (Fujita et al., } \\
\text { 2008) }\end{array}$ \\
\hline
\end{tabular}

Table 1. Proteins involved in both autophagy and exocytosis

In addition to its well documented role in exocytosis, recent evidence from mammalian cell cultures indicates that RalB is involved in the formation of autophagosomes (Bodemann et al., 2011). The crucial role for RalB as an upstream activator of autophagy is illustrated by the fact that the over-expression of its active GTP-bound form was sufficient to induce autophagy, even in the absence of autophagy-specific stimuli (Bodemann et al., 2011). RalB is present on sites of nascent autophagosome formation, together with Beclin1 and Atg5, and its depletion, similar to the depletion of Atg5 and Beclin1, significantly impaired the formation of starvation-induced LC3/Atg8 punctae and the turnover of LC3/Agt8. Interestingly, depletion of RalB also impaired the digestion of autophagocytosed Salmonella typhimurium. The autophagy-related function of RalB appears to be mediated by its effector Exo84, a component of the exocyst complex (Bodemann et al., 2011). Activated by starvation, RalB triggers Exo84 interaction with the autophagy initiation component Beclin1. Intriguingly, the alternative RalB roles in exocytosis and autophagy appear to be driven by environmental signal/s, as nutrient availability determines the RalB coupling preferences to a down-stream effector; endogenous RalB preferentially associates with Exo84 in nutrient poor conditions and with Sec5 under nutrient rich conditions (Bodemann et al., 2011). This model has not been investigated in higher eukaryotes, but these findings in yeast suggest a role for the exocyst complex as a scaffold for the assembly of a number of important autophagy initiators.

\subsubsection{Yeast Rab small GTPase Sec4}

The yeast Rab GTPase Sec4 and its activator Sec2 have well-established roles in the tethering of secretory vesicles to sites of active exocytosis, in a process mediated by interaction with the exocyst complex component Sec15 (Geng et al., 2010) . Recent studies indicate that Sec2 and Sec4 also have a role in anterograde trafficking of the autophagic membrane protein Atg9, as silencing of Sec4 blocked the delivery of Atg9 to the pre-autophagosomal structure 
(Geng et al., 2010). Furthermore, when the domain of Sec4 that is known to interact with Sec15 was altered, the effect on autophagy was equivalent to the effect of Sec4 silencing. Taking into account that there is no apparent role for Sec15 in autophagy, this suggests that autophagy-specific proteins may compete for this Sec15-binding domain in order to switch the function of activated GTP-bound Sec4 between exocytosis and autophagy.

\subsubsection{Metazoan Rab11 small GTPase}

Rab11 is a small GTPase, which is most often referred to as a recycling endosome marker. However, it has also been observed on vesicles bound for exocytosis (Shandala et al., 2011; Ward et al., 2005), and amphisomes; an intermediate compartment that is formed during autophagosome maturation, prior to lysosomal fusion (Fader \& Colombo, 2009)

The exocytic role for Rab11 is mediated by its association with the Sec15 exocyst component. This has been shown in MSCK cells (Oztan et al., 2007; Zhang et al., 2004), and in Drosophila photoreceptor and sensory neuron cells (Wu et al., 2005). Rab11 is important for the anterograde trafficking of; numerous membrane receptors (Chernyshova et al., 2011), the epithelial sodium channel complex of the cortical collecting duct of the kidneys (Butterworth et al., 2012), and DE-Cadherin in polarised cells (Langevin et al., 2005; Wu et al., 2005; Zhang et al., 2004), as well as the calcium dependent exocytosis of growth hormones (Ren et al., 1998; Takaya et al., 2007). A number of intracellular pathogens, such as Porphyromonas gingivalis, influenza A and HIV, have been reported to hi-jack Rab11 dependent anterograde trafficking as a means of escape from host cells (Kadiu \& Gendelman, 2011; Momose et al., 2011; Takeuchi et al., 2011).

An example of coordinated exocytosis and autophagy comes from the biology of multivesicular bodies (MVBs). MVBs are specialised late endosomes, a crucial intermediate in the internalization of nutrients, ligands and receptors into small intraluminal vesicles, also known as exosomes (Fader \& Colombo, 2009). Rab11 decorates MVBs and is involved in both the biogenesis of MVBs and exosome release (Fader et al., 2008). During the maturation of hematopoietic progenitors into reticulocytes and erythrocytes, proteins that are not required at the mature stage are sequestered into exosomes of MVBs. In this scenario Rab11 is involved in the targeting of MVBs to the plasma membrane, where exosomes are released into the extracellular milieu (Fader \& Colombo, 2006). Active Rab11 is also required for the interaction of MVBs with autophagosomes, where the resulting calcium-stimulated fusion of these organelles promotes efficient degradation of autophagic contents (Fader et al., 2008; Savina et al., 2005). Thus, Rab11 may represent a critical regulator of membrane flow between recycling endosomes (as a source of exocytic vesicles) and multivesicular bodies, where it can be engaged in both autophagic maturation and secretion.

\subsection{The exocyst and the initiation of autophagy}

Components of the exocyst complex involved in regulated and polarized exocytosis have also been shown to associate with a number of essential autophagy proteins (Bodemann et al., 2011). Exocyst components Sec3 and Sec8 interact in vitro with positive (FIP200, ATG14L) and negative (RUBICON) regulators of autophagy, as well as with the phagophore expansion complex Atg5-Atg12 (Bodemann et al., 2011). The functionality of these physical interactions is confirmed by the fact that LC3/Atg8 autophagosome formation was impaired 
in cells depleted for core exocyst components. For example, the depletion of Sec8 rendered cells insensitive to starvation stimulation, and impaired autophagy to the same extent as seen for the depletion of Atg5 and Beclin1 (Bodemann et al., 2011). Further interrogation of this system showed that the localization of exocyst components, with the autophagy initiator Atg1/Ulk1 and other proteins involved in isolation membrane formation, was altered following the induction of autophagy (Bodemann et al., 2011). As these processes are under the control of Ral or Rab, the differential recruitment of the exocyst to the target membrane might depend on the signals upstream of these small GTPases.

\subsection{SNARE proteins and membrane fusion during exocytosis and autophagy}

Both autophagosome maturation and anterograde vesicle trafficking via the exocytic route involve a series of membrane fusion steps, the execution of which is controlled by SNAREs. Recent studies in yeast have indicated that some exocytic t-SNAREs may also play a role in membrane dynamics during autophagy (Geng et al., 2010; Nair et al., 2011). The anterograde trafficking of the key autophagic membrane determinant, Atg9, depends on interaction with exocytic Sso1-Sec9, as well as on the endosomal t-SNARE Tlg2 and the v-SNAREs Sec22 and Ykt6. Sso1/2 and Sec9 SNAREs are also responsible for the formation of the Atg9 associated tubular-vesicular clusters emanating from the pre-autophagosomal structure, and their depletion results in Atg9 localization to small vesicular structures, possibly trans-Golgi network derived secretory vesicles, that fail to be delivered to the pre-autophagosomal structure (Nair et al., 2011). This failure of Atg9 delivery to pre-autophagosomal structure abolishes Atg8 recruitment, and thereby abrogates autophagosome biogenesis (Geng et al., 2010; Nair et al., 2011) .

Another group of SNAREs, the vesicle-associated membrane proteins (VAMPs), appear to be involved in membrane fusion events in both autophagy and exocytosis. One the one hand, during autophagosome maturation, it has been shown that VAMP3 and VAMP7 are required for sequential fusion with multivesicular bodies and lysosomes respectively (Fader et al., 2009). In HeLa cells, VAMP7 has been shown to be involved in homotypic fusion of Atg16L1 positive vesicles to allow autophagosome biogenesis (Moreau et al., 2011). On the other hand, it has been recently demonstrated that VAMP7 is involved in constitutive exocytosis in HSY cells (Oishi et al., 2006), and in apical trafficking of exocytic vesicles in polarized epithelial cells, such as MDCK cells and CaCo-2 cells (Galli et al., 1998). VAMP3 has been postulated to be a v-SNARE for early and recycling endosomes, with a role in constitutive exocytosis, but its role might be redundant as mice with a null mutation for this gene were normal in most endocytic and exocytic pathways, including constitutive exocytosis (Wang et al., 2004; Yang et al., 2001). The question remains whether these functions of SNAREs are restricted to specific tissues, or universal for all tissues, and if so, what are the upstream signals that direct these SNAREs to either the exocytic or autophagic membranes?

\subsection{The role of autophagy genes in secretion}

There is emerging evidence of involvement of autophagy proteins in polarized secretion involving lysosomes. In bone resorptive osteoclasts, Atg5, Atg7, Atg4B, and LC3/Atg8 participate in directing lysosomes to fuse with the plasma membrane and in the release of the lytic enzyme cathepsin K into the extracellular space (DeSelm et al., 2011). This type of 
lysosome-regulated exocytosis is not restricted to osteoclasts involved in bone remodelling, and has been described for lysosome related organelles in many other specialist cell types, such as melanosomes in melanocytes and lytic granules in neutrophils (Blott \& Griffiths, 2002; Chen et al., 2012; Luzio et al., 2007). In yeast grown under conditions of nitrogen starvation, autophagy genes are required for the secretion of an acyl coenzyme A binding protein (Acb1) (Bruns et al., 2011; Duran et al., 2010; Manjithaya et al., 2010; Skinner, 2010). This unconventional route of secretion is initiated at sites that are positive for the Golgi assembly and stacking protein (GRASP65) homologue 1 (Grh1), which attracts core autophagy-related proteins Atg9 and Atg8 to a novel compartment (Bruns et al., 2011). These Acb1-containing autophagosomes then evade fusion with the lytic vacuole, fusing instead with recycling endosomes to form multivesicular body carriers, which then fuse with the plasma membrane in a t-SNARE Sso1 dependent fashion, to release Acb1. It is still not clear how beneficial or economical it is for cells to use these unconventional routes of secretion.

\section{Summary}

Despite the similarity in requirements for membrane dynamics in the processes of exocytosis and autophagy, correlations between the molecular machinery used for both of these processes are only beginning to be elucidated. The exocytic and autophagic functions of cells are critical for the maintenance of cell homeostasis and the exchange of membrane between intracellular compartments and the cell surface. In addition, the fusion and fission events that remodel the exocytic vesicle and the autophagosome are likely to require much of the same molecular machinery. Therefore, it is likely that there is co-ordinated control of these two processes to ensure that they can be regulated with respect to each other. Members of the exocyst complex, and some autophagy related proteins, have already been shown to have functions in their opposite processes, and the involvement of the Ral small GTPases in the global control of exocytosis and autophagy mirrors the role of Rab small GTPases in the control of endosome trafficking. There are many intriguing questions brought about by recent findings. What is the decision making signal that diverges the components of the shared machinery from one pathway to another? Is there a common upstream signal for both pathways, be it through the insulin receptor/mTOR (Webber \& Tooze, 2010), MAPK (Webber \& Tooze, 2010), redox (Lee et al., 2012), or are there combinations of these signals? Or is there a yet to be defined intrinsic factor of the autophagic or exocytic membrane, with a changing affinity for vesicular compartments? This is a very interesting time to be exploring the intersection of the exocytosis and autophagy pathways, particularly while we are is still looking for the key controllers of cellular homeostasis in cancers, neurodegenerative and immune disorders.

\section{References}

Aalto, M. K., Ronne, H. \& Keranen, S. (1993). Yeast syntaxins Sso1p and Sso2p belong to a family of related membrane proteins that function in vesicular transport. The EMBO journal, Vol. 12, No.11 (November 1993), pp.4095-4104, 0261-4189

Aita, V. M., Liang, X. H., Murty, V. V., Pincus, D. L., Yu, W., Cayanis, E., Kalachikov, S., Gilliam, T. C. \& Levine, B. (1999). Cloning and genomic organization of beclin 1, a 
candidate tumor suppressor gene on chromosome 17q21. Genomics, Vol. 59, No.1 (July 1999), pp.59-65, 0888-7543

Bae, Y. J., Kang, S. J. \& Park, K. S. (2007). Drosophila melanogaster Parkin ubiquitinates peanut and septin1 as an E3 ubiquitin-protein ligase. Insect biochemistry and molecular biology, Vol. 37, No.5 (May 2007), pp.430-439, 0965-1748

Balasubramanian, N., Meier, J. A., Scott, D. W., Norambuena, A., White, M. A. \& Schwartz, M. A. (2010). RalA-exocyst complex regulates integrin-dependent membrane raft exocytosis and growth signaling. Current biology : CB, Vol. 20, No.1 (January 2010), pp.75-79, 0960-9822

Bao, Y., Lopez, J. A., James, D. E. \& Hunziker, W. (2008). Snapin interacts with the Exo70 subunit of the exocyst and modulates GLUT4 trafficking. The Journal of biological chemistry, Vol. 283, No.1 (January 2008), pp.324-331, 0021-9258

Barbier, M. (2003). Overexpression of leptin mRNA in mesenteric adipose tissue in inflammatory bowel diseases. Gastroentérologie clinique et biologique, Vol. 27, No.11 (November 2003), pp.987-991, 0399-8320

Barg, S. \& Machado, J. D. (2008). Compensatory endocytosis in chromaffin cells. Acta physiologica, Vol. 192, No.2 (February 2008), pp.195-201, 1748-1708

Barrett, J. C. (2008). Genome-wide association defines more than 30 distinct susceptibility loci for Crohn's disease. Nature genetics, Vol. 40, No.8 (August 2008), pp.955-962, 1061-4036

Bilder, D., Li, M. \& Perrimon, N. (2000). Cooperative regulation of cell polarity and growth by Drosophila tumor suppressors. Science, Vol. 289, No.5476 (July 2000), pp.113-116, 0036-8075

Blott, E. J. \& Griffiths, G. M. (2002). Secretory lysosomes. Nature reviews. Molecular cell biology, Vol. 3, No.2 (February 2002), pp.122-131, 1471-0072

Bodemann, B. O., Orvedahl, A., Cheng, T., Ram, R. R., Ou, Y. H., Formstecher, E., Maiti, M., Hazelett, C. C., Wauson, E. M., Balakireva, M., Camonis, J. H., Yeaman, C., Levine, B. \& White, M. A. (2011). RalB and the exocyst mediate the cellular starvation response by direct activation of autophagosome assembly. Cell, Vol. 144, No.2 (January 2011), pp.253-267, 0092-8674

Boucrot, E. \& Kirchhausen, T. (2007). Endosomal recycling controls plasma membrane area during mitosis. Proceedings of the National Academy of Sciences of the United States of America, Vol. 104, No.19 (May 2007), pp.7939-7944, 0027-8424

Boya, P., Gonzalez-Polo, R. A., Casares, N., Perfettini, J. L., Dessen, P., Larochette, N., Metivier, D., Meley, D., Souquere, S., Yoshimori, T., Pierron, G., Codogno, P. \& Kroemer, G. (2005). Inhibition of macroautophagy triggers apoptosis. Molecular and cellular biology, Vol. 25, No.3 (February 2005), pp.1025-1040, 0270-7306

Brennwald, P., Kearns, B., Champion, K., Keranen, S., Bankaitis, V. \& Novick, P. (1994). Sec9 is a SNAP-25-like component of a yeast SNARE complex that may be the effector of Sec4 function in exocytosis. Cell, Vol. 79, No.2 (October 1994), pp.245-258, 0092-8674

Brennwald, P. \& Rossi, G. (2007). Spatial regulation of exocytosis and cell polarity: yeast as a model for animal cells. FEBS letters, Vol. 581, No.11 (May 2007), pp.2119-2124, 00145793 
Bruns, C., McCaffery, J. M., Curwin, A. J., Duran, J. M. \& Malhotra, V. (2011). Biogenesis of a novel compartment for autophagosome-mediated unconventional protein secretion. The Journal of cell biology, Vol. 195, No.6 (December 2011), pp.979-992, 0021-9525

Brymora, A., Valova, V. A., Larsen, M. R., Roufogalis, B. D. \& Robinson, P. J. (2001). The brain exocyst complex interacts with RalA in a GTP-dependent manner: identification of a novel mammalian Sec3 gene and a second Sec15 gene. The Journal of biological chemistry, Vol. 276, No.32 (August 2001), pp.29792-29797, 0021-9258

Butterworth, M. B., Edinger, R. S., Silvis, M. R., Gallo, L. I., Liang, X., Apodaca, G., Frizzell, R. A. \& Johnson, J. P. (2012). Rab11b regulates the trafficking and recycling of the epithelial sodium channel (ENaC). American journal of physiology. Renal physiology, Vol. 302, No.5 (March 2012), pp.F581-F590, 1522-1466

Cadwell, K., Liu, J. Y., Brown, S. L., Miyoshi, H., Loh, J., Lennerz, J. K., Kishi, C., Kc, W., Carrero, J. A., Hunt, S., Stone, C. D., Brunt, E. M., Xavier, R. J., Sleckman, B. P., Li, E., Mizushima, N., Stappenbeck, T. S. \& Virgin Iv, H. W. (2008). A key role for autophagy and the autophagy gene Atg1611 in mouse and human intestinal Paneth cells. Nature, Vol. 456, No.7219 (November 2008), pp.259-263, 0028-0836

Cadwell, K., Patel, K. K., Komatsu, M., Virgin, H. W. t. \& Stappenbeck, T. S. (2009). A common role for Atg16L1, Atg5 and Atg7 in small intestinal Paneth cells and Crohn disease. Autophagy, Vol. 5, No.2 (February 2009), pp.250-252, 1554-8627

Cadwell, K., Patel, K. K., Maloney, N. S., Liu, T.-C., Ng, A. C. Y., Storer, C. E., Head, R. D., Xavier, R., Stappenbeck, T. S. \& Virgin, H. W. (2010). Virus-plus-susceptibility gene interaction determines Crohn's disease gene Atg16L1 phenotypes in intestine. Cell, Vol. 141, No.7 (June 2010), pp.1135-1145, 0092-8674

Cardoso, C. M., Groth-Pedersen, L., Hoyer-Hansen, M., Kirkegaard, T., Corcelle, E., Andersen, J. S., Jaattela, M. \& Nylandsted, J. (2009). Depletion of kinesin 5B affects lysosomal distribution and stability and induces peri-nuclear accumulation of autophagosomes in cancer cells. PLoS one, Vol. 4, No.2 (February 2009), pp.e4424, 1932-6203

Chang, Y. Y. \& Neufeld, T. P. (2009). An Atg1/Atg13 complex with multiple roles in TORmediated autophagy regulation. Molecular biology of the cell, Vol. 20, No.7 (April 2009), pp.2004-2014, 1059-1524

Chang, Y. Y. \& Neufeld, T. P. (2010). Autophagy takes flight in Drosophila. FEBS letters, Vol. 584, No.7 (April 2010), pp.1342-1349, 0014-5793

Chen, G., Zhang, Z., Wei, Z., Cheng, Q., Li, X., Li, W., Duan, S. \& Gu, X. (2012). Lysosomal exocytosis in Schwann cells contributes to axon remyelination. Glia, Vol. 60, No.2 (February 2012), pp.295-305, 0894-1491

Chen, X. W., Leto, D., Chiang, S. H., Wang, Q. \& Saltiel, A. R. (2007). Activation of RalA is required for insulin-stimulated Glut4 trafficking to the plasma membrane via the exocyst and the motor protein Myo1c. Developmental cell, Vol. 13, No.3 (September 2007), pp.391-404, 1534-5807

Chen, X. W., Leto, D., Xiao, J., Goss, J., Wang, Q., Shavit, J. A., Xiong, T., Yu, G., Ginsburg, D., Toomre, D., Xu, Z. \& Saltiel, A. R. (2011a). Exocyst function is regulated by 
effector phosphorylation. Nature cell biology, Vol. 13, No.5 (May 2011), pp.580-588, 1465-7392

Chen, X. W., Leto, D., Xiong, T., Yu, G., Cheng, A., Decker, S. \& Saltiel, A. R. (2011b). A Ral GAP complex links PI 3-kinase/Akt signaling to RalA activation in insulin action. Molecular biology of the cell, Vol. 22, No.1 (January 2011), pp.141-152, 1939-4586

Chernyshova, Y., Leshchyns'ka, I., Hsu, S. C., Schachner, M. \& Sytnyk, V. (2011). The neural cell adhesion molecule promotes FGFR-dependent phosphorylation and membrane targeting of the exocyst complex to induce exocytosis in growth cones. The Journal of neuroscience, Vol. 31, No.10 (March 2011), pp.3522-3535, 0270-6474

DeSelm, C. J., Miller, B. C., Zou, W., Beatty, W. L., van Meel, E., Takahata, Y., Klumperman, J., Tooze, S. A., Teitelbaum, S. L. \& Virgin, H. W. (2011). Autophagy proteins regulate the secretory component of osteoclastic bone resorption. Developmental cell, Vol. 21, No.5 (November 2011), pp.966-974, 1534-5807

Dupraz, S., Grassi, D., Bernis, M. E., Sosa, L., Bisbal, M., Gastaldi, L., Jausoro, I., Caceres, A., Pfenninger, K. H. \& Quiroga, S. (2009). The TC10-Exo70 complex is essential for membrane expansion and axonal specification in developing neurons. The Journal of neuroscience, Vol. 29, No.42 (October 2009), pp.13292-13301, 0270-6474

Duran, J. M., Anjard, C., Stefan, C., Loomis, W. F. \& Malhotra, V. (2010). Unconventional secretion of Acb1 is mediated by autophagosomes. The Journal of cell biology, Vol. 188, No.4 (February 2010), pp.527-536, 0021-9525

Engisch, K. L. \& Nowycky, M. C. (1998). Compensatory and excess retrieval: two types of endocytosis following single step depolarizations in bovine adrenal chromaffin cells. The Journal of physiology, Vol. 506, No.3 (February 1998), pp.591-608, 0022-3751

Eskelinen, E. L. (2005). Maturation of autophagic vacuoles in mammalian cells. Autophagy, Vol. 1, No.1 (April 2006), pp.1-10, 1554-8627

Fader, C. M. \& Colombo, M. I. (2006). Multivesicular bodies and autophagy in erythrocyte maturation. Autophagy, Vol. 2, No.2 (April 2006), pp.122-125, 1554-8627

Fader, C. M., Sanchez, D., Furlan, M. \& Colombo, M. I. (2008). Induction of autophagy promotes fusion of multivesicular bodies with autophagic vacuoles in k562 cells. Traffic, Vol. 9, No.2 (February 2008), pp.230-250, 1398-9219

Fader, C. M. \& Colombo, M. I. (2009). Autophagy and multivesicular bodies: two closely related partners. Cell death and differentiation, Vol. 16, No.1 (January 2009), pp.70-78, 1350-9047

Fader, C. M., Sanchez, D. G., Mestre, M. B. \& Colombo, M. I. (2009). TI-VAMP/VAMP7 and VAMP3/cellubrevin: two v-SNARE proteins involved in specific steps of the autophagy/multivesicular body pathways. Biochimica et biophysica acta, Vol. 1793, No.12 (December 2009), pp.1901-1916, 0006-3002

Farr, G. A., Hull, M., Mellman, I. \& Caplan, M. J. (2009). Membrane proteins follow multiple pathways to the basolateral cell surface in polarized epithelial cells. The Journal of cell biology, Vol. 186, No.2 (July 2009), pp.269-282, 0021-9525

Farré, J.-C. \& Subramani, S. (2011). Rallying the exocyst as an autophagy scaffold. Cell, Vol. 144, No.2 (January 2011), pp.172-174, 0092-8674

Feig, L. A. (2003). Ral-GTPases: approaching their 15 minutes of fame. Trends in cell biology, Vol. 13, No.8 (August 2003), pp.419-425, 0962-8924 
Franken, S., Junghans, U., Rosslenbroich, V., Baader, S. L., Hoffmann, R., Gieselmann, V., Viebahn, C. \& Kappler, J. (2003). Collapsin response mediator proteins of neonatal rat brain interact with chondroitin sulfate. The Journal of biological chemistry, Vol. 278, No.5 (January 2003), pp.3241-3250, 0021-9258

Fujita, N., Itoh, T., Fukuda, M., Noda, T. \& Yoshimori, T. (2008). The Atg16L complex specifies the site of LC3 lipidation for membrane biogenesis in autophagy. Molecular biology of the cell, Vol. 19, No.5 (May 2008), pp.2092-2100, 1059-1524

Fukai, S., Matern, H. T., Jagath, J. R., Scheller, R. H. \& Brunger, A. T. (2003). Structural basis of the interaction between RalA and Sec5, a subunit of the sec6/8 complex. The EMBO journal, Vol. 22, No.13 (July 2003), pp.3267-3278, 0261-4189

Galli, T., Zahraoui, A., Vaidyanathan, V. V., Raposo, G., Tian, J. M., Karin, M., Niemann, H. \& Louvard, D. (1998). A novel tetanus neurotoxin-insensitive vesicle-associated membrane protein in SNARE complexes of the apical plasma membrane of epithelial cells. Molecular biology of the cell, Vol. 9, No.6 (June 1998), pp.1437-1448, 1059-1524

Gao, H.-M. \& Hong, J.-S. (2008). Why neurodegenerative diseases are progressive: uncontrolled inflammation drives disease progression. Trends in immunology, Vol. 29, No.8 (August 2008), pp.357-365, 1471-4906

Gateff, E. (1978). Malignant neoplasms of genetic origin in Drosophila melanogaster. Science, Vol. 200, No.4349 (June 1978), pp.1448-1459, 0036-8075

Geng, J., Nair, U., Yasumura-Yorimitsu, K. \& Klionsky, D. J. (2010). Post-Golgi Sec proteins are required for autophagy in Saccharomyces cerevisiae. Molecular biology of the cell, Vol. 21, No.13 (July 2010), pp.2257-2269, 1059-1524

Govind, S. (2008). Innate immunity in Drosophila: Pathogens and pathways. Insect science, Vol. 15, No.1 (February 2008), pp.29-43, 1672-9609

Gozuacik, D. \& Kimchi, A. (2006). DAPk protein family and cancer. Autophagy, Vol. 2, No.2 (April 2006), pp.74-79, 1554-8627

Guo, W., Roth, D., Walch-Solimena, C. \& Novick, P. (1999). The exocyst is an effector for Sec4p, targeting secretory vesicles to sites of exocytosis. The EMBO journal, Vol. 18, No.4 (February 1999), pp.1071-1080, 0261-4189

Gutierrez, M. G., Master, S. S., Singh, S. B., Taylor, G. A., Colombo, M. I. \& Deretic, V. (2004a). Autophagy is a defense mechanism inhibiting BCG and Mycobacterium tuberculosis survival in infected macrophages. Cell, Vol. 119, No.6 (December 2004), pp.753-766, 0092-8674

Gutierrez, M. G., Munafo, D. B., Beron, W. \& Colombo, M. I. (2004b). Rab7 is required for the normal progression of the autophagic pathway in mammalian cells. Journal of cell science, Vol. 117, No.13 (June 2004), pp.2687-2697, 0021-9533

Gutnick, A., Blechman, J., Kaslin, J., Herwig, L., Belting, H. G., Affolter, M., Bonkowsky, J. L. \& Levkowitz, G. (2011). The hypothalamic neuropeptide oxytocin is required for formation of the neurovascular interface of the pituitary. Developmental cell, Vol. 21, No.4 (October 2011), pp.642-654, 1534-5807

Hailey, D.W., Rambold, A.S., Satpute-Krishnan, P., Mitra, K., Sougrat, R., Kim, P.K. \& Lippincott-Schwartz, J. (2010). Mitochondria supply membranes for 
autophagosome biogenesis during starvation. Cell, Vol. 141, No.4 (May 2010), pp.656-667, 0092-8674

Hamasaki, M. \& Yoshimori, T. (2010). Where do they come from? Insights into autophagosome formation. FEBS letters, Vol. 584, No.7 (April 2010), pp.1296-1301, 0014-5793

Hara, T. (2006). Suppression of basal autophagy in neural cells causes neurodegenerative disease in mice. Nature, Vol. 441, No.7095 (June 2006), pp.885-889, 0028-0836

Hattendorf, D. A., Andreeva, A., Gangar, A., Brennwald, P. J. \& Weis, W. I. (2007). Structure of the yeast polarity protein Sro7 reveals a SNARE regulatory mechanism. Nature, Vol. 446, No.7135 (March 2007), pp.567-571, 0028-0836

He, B., Xi, F., Zhang, X., Zhang, J. \& Guo, W. (2007). Exo70 interacts with phospholipids and mediates the targeting of the exocyst to the plasma membrane. The EMBO journal, Vol. 26, No.18 (September 2007), pp.4053-4065, 0261-4189

He, B. \& Guo, W. (2009). The exocyst complex in polarized exocytosis. Current opinion in cell biology, Vol. 21, No.4 (August 2009), pp.537-542, 0955-0674

He, C., Baba, M. \& Klionsky, D. J. (2009). Double duty of Atg9 self-association in autophagosome biogenesis. Autophagy, Vol. 5, No.3 (April 2009), pp.385-387, 15548627

He, C. \& Klionsky, D. J. (2009). Regulation mechanisms and signaling pathways of autophagy. Annual review of genetics, Vol. 43, (December 2009), pp.67-93, 0066-4197

Hippert, M. M., O'Toole, P. S. \& Thorburn, A. (2006). Autophagy in cancer: good, bad, or both? Cancer research, Vol. 66, No.19 (October 2006), pp.9349-9351, 0008-5472

Homer, C. R., Richmond, A. L., Rebert, N. A., Achkar, J. P. \& McDonald, C. (2010). ATG16L1 and NOD2 interact in an autophagy-dependent antibacterial pathway implicated in Crohn's disease pathogenesis. Gastroenterology, Vol. 139, No.5 (November 2010), pp.1630-1641, 0016-5085

$\mathrm{Hu}, \mathrm{Z}$., Zhang, J. \& Zhang, Q. (2011). Expression pattern and functions of autophagy-related gene atg5 in zebrafish organogenesis. Autophagy, Vol. 7, No.12 (December 2011), pp.1514-1527, 1554-8627

Ichimura, Y., Kirisako, T., Takao, T., Satomi, Y., Shimonishi, Y., Ishihara, N., Mizushima, N., Tanida, I., Kominami, E., Ohsumi, M., Noda, T. \& Ohsumi, Y. (2000). A ubiquitinlike system mediates protein lipidation. Nature, Vol. 408, No.6811 (November 2000), pp.488-492, 0028-0836

Inoue, M., Chang, L., Hwang, J., Chiang, S. H. \& Saltiel, A. R. (2003). The exocyst complex is required for targeting of Glut4 to the plasma membrane by insulin. Nature, Vol. 422, No.6932 (April 2003), pp.629-633, 0028-0836

Inoue, M., Chiang, S. H., Chang, L., Chen, X. W. \& Saltiel, A. R. (2006). Compartmentalization of the exocyst complex in lipid rafts controls Glut4 vesicle tethering. Molecular biology of the cell, Vol. 17, No.5 (May 2006), pp.2303-2311, 10591524

Jin, Y., Sultana, A., Gandhi, P., Franklin, E., Hamamoto, S., Khan, A. R., Munson, M., Schekman, R. \& Weisman, L. S. (2011). Myosin V transports secretory vesicles via a Rab GTPase cascade and interaction with the exocyst complex. Developmental cell, Vol. 21, No.6 (December 2011), pp.1156-1170, 1534-5807 
Kadiu, I. \& Gendelman, H. E. (2011). Human Immunodeficiency Virus type 1 endocytic trafficking through macrophage bridging conduits facilitates spread of infection. Journal of neuroimmune pharmacology, Vol. 6, No.4 (December 2011), pp.658-675, 1557-1890

Kamada, Y., Funakoshi, T., Shintani, T., Nagano, K., Ohsumi, M. \& Ohsumi, Y. (2000). Tormediated induction of autophagy via an Apg1 protein kinase complex. The Journal of cell biology, Vol. 150, No.6 (Sepember 2000), pp.1507-1513, 0021-9525

Kawato, M., Shirakawa, R., Kondo, H., Higashi, T., Ikeda, T., Okawa, K., Fukai, S., Nureki, O., Kita, T. \& Horiuchi, H. (2008). Regulation of platelet dense granule secretion by the Ral GTPase-exocyst pathway. The Journal of biological chemistry, Vol. 283, No.1 (January 2007), pp.166-174, 0021-9258

Keating, D. J. (2008). Mitochondrial dysfunction, oxidative stress, regulation of exocytosis and their relevance to neurodegenerative diseases. Journal of neurochemistry, Vol. 104, No.2 (January 2008), pp.298-305, 0022-3042

Khandelwal, P., Ruiz, W. G., Balestreire-Hawryluk, E., Weisz, O. A., Goldenring, J. R. \& Apodaca, G. (2008). Rab11a-dependent exocytosis of discoidal/fusiform vesicles in bladder umbrella cells. Proceedings of the National Academy of Sciences of the United States of America, Vol. 105, No.41 (October 2008), pp.15773-15778, 0027-8424

Khandelwal, P., Ruiz, W. G. \& Apodaca, G. (2010). Compensatory endocytosis in bladder umbrella cells occurs through an integrin-regulated and RhoA- and dynamindependent pathway. The EMBO journal, Vol. 29, No.12 (June 2010), pp.1961-1975, 0261-4189

Kim, J. H. \& von Gersdorff, H. (2009). Traffic jams during vesicle cycling lead to synaptic depression. Neuron, Vol. 63, No.2 (July 2009), pp.143-145, 0896-6273

Kim, K. S., Park, J. Y., Jou, I. \& Park, S. M. (2010). Regulation of Weibel-Palade body exocytosis by alpha-synuclein in endothelial cells. The Journal of biological chemistry, Vol. 285, No.28 (July 2010), pp.21416-21425, 0021-9258

Koike, M., Shibata, M., Waguri, S., Yoshimura, K., Tanida, I., Kominami, E., Gotow, T., Peters, C., von Figura, K., Mizushima, N., Saftig, P. \& Uchiyama, Y. (2005). Participation of autophagy in storage of lysosomes in neurons from mouse models of neuronal ceroid-lipofuscinoses (Batten disease). American journal of pathology, Vol. 167, No.6 (December 2005), pp.1713-1728, 0002-9440

Komatsu, M., Waguri, S., Chiba, T., Murata, S., Iwata, J., Tanida, I., Ueno, T., Koike, M., Uchiyama, Y., Kominami, E. \& Tanaka, K. (2006). Loss of autophagy in the central nervous system causes neurodegeneration in mice. Nature, Vol. 441, No.7095 (June 2006), pp.880-884, 0028-0836

Kundu, M. \& Thompson, C. B. (2008). Autophagy: basic principles and relevance to disease. Annual review of pathology, Vol. 3, (February 2008), pp.427-455, 1553-4006

Kundu, M. (2011). ULK1, mammalian target of rapamycin, and mitochondria: linking nutrient availability and autophagy. Antioxidants \& redox signaling, Vol. 14, No.10 (May 2011), pp.1953-1958, 1523-0864

Langevin, J., Morgan, M. J., Sibarita, J. B., Aresta, S., Murthy, M., Schwarz, T., Camonis, J. \& Bellaiche, Y. (2005). Drosophila exocyst components Sec5, Sec6, and Sec15 regulate 
DE-Cadherin trafficking from recycling endosomes to the plasma membrane. Developmental cell, Vol. 9, No.3 (September 2005), pp.365-376, 1534-5807

Lee, J., Giordano, S. \& Zhang, J. (2012). Autophagy, mitochondria and oxidative stress: cross-talk and redox signalling. The biochemical journal, Vol. 441, No.2 (January 2012), pp.523-540, 0264-6021

Levine, B. (2007). Cell biology: autophagy and cancer. Nature, Vol. 446, No.7137 (April 2007), pp.745-747, 0028-0836

Levine, B. \& Kroemer, G. (2008). Autophagy in the pathogenesis of disease. Cell, Vol. 132, No.1 (January 2008), pp.27-42, 0092-8674

Li, G., Han, L., Chou, T. C., Fujita, Y., Arunachalam, L., Xu, A., Wong, A., Chiew, S. K., Wan, Q., Wang, L. \& Sugita, S. (2007). RalA and RalB function as the critical GTP sensors for GTP-dependent exocytosis. The Journal of neuroscience, Vol. 27, No.1 (January 2007), pp.190-202, 0270-6474

Lindmo, K., Simonsen, A., Brech, A., Finley, K., Rusten, T. E. \& Stenmark, H. (2006). A dual function for Deep orange in programmed autophagy in the Drosophila melanogaster fat body. Experimental cell research, Vol. 312, No.11 (July 2006), pp.2018-2027, 00144827

Lipschutz, J. H. \& Mostov, K. E. (2002). Exocytosis: the many masters of the exocyst. Current biology: CB, Vol. 12, No.6 (March 2002), pp.R212-214, 0960-9822

Liu, J., Zuo, X., Yue, P. \& Guo, W. (2007). Phosphatidylinositol 4,5-bisphosphate mediates the targeting of the exocyst to the plasma membrane for exocytosis in mammalian cells. Molecular biology of the cell, Vol. 18, No.11 (November 2007), pp.4483-4492, 1059-1524

Liu, J. \& Guo, W. (2011). The exocyst complex in exocytosis and cell migration. Protoplasma, DOI: 10.1007/s00709-011-0330-1 (October 2011), 0033-183X

Ljubicic, S., Bezzi, P., Vitale, N. \& Regazzi, R. (2009). The GTPase RalA regulates different steps of the secretory process in pancreatic beta-cells. PloS one, Vol. 4, No.11 (November 2009), pp.e7770, 1932-6203

Llobet, A., Gallop, J. L., Burden, J. J., Camdere, G., Chandra, P., Vallis, Y., Hopkins, C. R., Lagnado, L. \& McMahon, H. T. (2011). Endophilin drives the fast mode of vesicle retrieval in a ribbon synapse. The Journal of neuroscience, Vol. 31, No.23 (June 2011), pp.8512-8519, 0270-6474

Logiudice, L., Sterling, P. \& Matthews, G. (2009). Vesicle recycling at ribbon synapses in the finely branched axon terminals of mouse retinal bipolar neurons. Neuroscience, Vol. 164, No.4 (December 2009), pp.1546-1556, 0306-4522

Lopez, J. A., Kwan, E. P., Xie, L., He, Y., James, D. E. \& Gaisano, H. Y. (2008). The RalA GTPase is a central regulator of insulin exocytosis from pancreatic islet beta cells. The Journal of biological chemistry, Vol. 283, No.26 (June 2008), pp.17939-17945, 00219258

Luzio, J. P., Pryor, P. R. \& Bright, N. A. (2007). Lysosomes: fusion and function. Nature reviews. Molecular cell biology, Vol. 8, No.8 (August 2007), pp.622-632, 1471-0072

Malacombe, M., Ceridono, M., Calco, V., Chasserot-Golaz, S., McPherson, P. S., Bader, M. F. \& Gasman, S. (2006). Intersectin-1L nucleotide exchange factor regulates secretory 
granule exocytosis by activating Cdc42. The EMBO journal, Vol. 25, No.15 (August 2006), pp.3494-3503, 0261-4189

Manjithaya, R., Anjard, C., Loomis, W. F. \& Subramani, S. (2010). Unconventional secretion of Pichia pastoris Acb1 is dependent on GRASP protein, peroxisomal functions, and autophagosome formation. The Journal of cell biology, Vol. 188, No.4 (February 2010), pp.537-546, 0021-9525

Mari, M., Griffith, J., Rieter, E., Krishnappa, L., Klionsky, D. J. \& Reggiori, F. (2010). An Atg9-containing compartment that functions in the early steps of autophagosome biogenesis. The Journal of cell biology, Vol. 190, No.6 (September 2010), pp.1005-1022, 0021-9525

Mari, M. \& Reggiori, F. (2010). Atg9 reservoirs, a new organelle of the yeast endomembrane system? Autophagy, Vol. 6, No.8 (November 2010), pp.1221-1223, 1554-8627

Mark, B. L., Jilkina, O. \& Bhullar, R. P. (1996). Association of Ral GTP-binding protein with human platelet dense granules. Biochemical and biophysical research communications, Vol. 225, No.1 (August 1996), pp.40-46, 0006-291X

McPhee, C. K. \& Baehrecke, E. H. (2009). Autophagy in Drosophila melanogaster. Biochimica et biophysica acta, Vol. 1793, No.9 (September 2009), pp.1452-1460, 0006-3002

Mehrpour, M., Esclatine, A., Beau, I. \& Codogno, P. (2010). Overview of macroautophagy regulation in mammalian cells. Cell research, Vol. 20, No.7 (July 2010), pp.748-762, 1001-0602

Meijer, A. J. \& Codogno, P. (2004). Regulation and role of autophagy in mammalian cells. The international journal of biochemistry \& cell biology, Vol. 36, No.12 (December 2004), pp.2445-2462, 1357-2725

Militello, R. D. \& Colombo, M. I. (2011). A membrane is born: origin of the autophagosomal compartment. Current molecular medicine, Vol. 11, No.3 (April 2011), pp.197-203, 1566-5240

Minty, C. A., Hall, N. D. \& Bacon, P. A. (1983). Depressed exocytosis by rheumatoid neutrophils in vitro. Rheumatology international, Vol. 3, No.3 (September 1983), pp.139-142, 0172-8172

Miracco, C., Cosci, E., Oliveri, G., Luzi, P., Pacenti, L., Monciatti, I., Mannucci, S., De Nisi, M. C., Toscano, M., Malagnino, V., Falzarano, S. M., Pirtoli, L. \& Tosi, P. (2007). Protein and mRNA expression of autophagy gene Beclin 1 in human brain tumours. International journal of oncology, Vol. 30, No.2 (February 2007), pp.429-436, 1019-6439

Mizushima, N., Noda, T., Yoshimori, T., Tanaka, Y., Ishii, T., George, M. D., Klionsky, D. J., Ohsumi, M. \& Ohsumi, Y. (1998). A protein conjugation system essential for autophagy. Nature, Vol. 395, No.6700 (September 1998), pp.395-398, 0028-0836

Momose, F., Sekimoto, T., Ohkura, T., Jo, S., Kawaguchi, A., Nagata, K. \& Morikawa, Y. (2011). Apical transport of influenza A virus ribonucleoprotein requires Rab11positive recycling endosome. PloS one, Vol. 6, No.6 (June 2011), pp.e21123, 19326203

Moreau, K., Ravikumar, B., Renna, M., Puri, C. \& Rubinsztein, D. C. (2011). Autophagosome precursor maturation requires homotypic fusion. Cell, Vol. 146, No.2 (July 2011), pp.303-317, 0092-8674 
Morgera, F., Sallah, M. R., Dubuke, M. L., Gandhi, P., Brewer, D. N., Carr, C. M. \& Munson, M. (2012). Regulation of exocytosis by the exocyst subunit Sec6 and the SM protein Sec1. Molecular biology of the cell, Vol. 23, No.2 (January 2012), pp. 337-346, 1059-1524

Moskalenko, S., Henry, D. O., Rosse, C., Mirey, G., Camonis, J. H. \& White, M. A. (2002). The exocyst is a Ral effector complex. Nature cell biology, Vol. 4, No.1 (January 2002), pp.66-72, 1465-7392

Mott, H. R., Nietlispach, D., Hopkins, L. J., Mirey, G., Camonis, J. H. \& Owen, D. (2003). Structure of the GTPase-binding domain of Sec5 and elucidation of its Ral binding site. The Journal of biological chemistry, Vol. 278, No.19 (May 2003), pp.17053-17059, 0021-9258

Murray, P. D., McGavern, D. B., Lin, X., Njenga, M. K., Leibowitz, J., Pease, L. R. \& Rodriguez, M. (1998). Perforin-dependent neurologic injury in a viral model of multiple sclerosis. The Journal of neuroscience, Vol. 18, No.18 (September 1998), pp.7306-7314, 0270-6474

Nair, U., Jotwani, A., Geng, J., Gammoh, N., Richerson, D., Yen, W. L., Griffith, J., Nag, S., Wang, K., Moss, T., Baba, M., McNew, J. A., Jiang, X., Reggiori, F., Melia, T. J. \& Klionsky, D. J. (2011). SNARE proteins are required for macroautophagy. Cell, Vol. 146, No.2 (July 2011), pp.290-302, 0092-8674

Nakatogawa, H., Ichimura, Y. \& Ohsumi, Y. (2007). Atg8, a ubiquitin-like protein required for autophagosome formation, mediates membrane tethering and hemifusion. Cell, Vol. 130, No.1 (July 2007), pp.165-178, 0092-8674

Nakatogawa, H., Suzuki, K., Kamada, Y. \& Ohsumi, Y. (2009). Dynamics and diversity in autophagy mechanisms: lessons from yeast. Nature reviews. Molecular cell biology, Vol. 10, No.7 (July 2009), pp.458-467, 1471-0072

Novick, P. \& Guo, W. (2002). Ras family therapy: Rab, Rho and Ral talk to the exocyst. Trends in cell biology, Vol. 12, No.6 (June 2002), pp.247-249, 0962-8924

Novick, P., Medkova, M., Dong, G., Hutagalung, A., Reinisch, K. \& Grosshans, B. (2006). Interactions between Rabs, tethers, SNAREs and their regulators in exocytosis. Biochemical Society transactions, Vol. 34, No.5 (November 2006), pp.683-686, 03005127

Oishi, Y., Arakawa, T., Tanimura, A., Itakura, M., Takahashi, M., Tajima, Y., Mizoguchi, I. \& Takuma, T. (2006). Role of VAMP-2, VAMP-7, and VAMP-8 in constitutive exocytosis from HSY cells. Histochemistry and cell biology, Vol. 125, No.3 (March 2006), pp.273-281, 0948-6143

Orlando, K. \& Guo, W. (2009). Membrane organization and dynamics in cell polarity. Cold Spring Harbor perspectives in biology, Vol. 1, No.5 (November 2009), pp.a001321, 1943-0264

Ostenson, C.-G., Gaisano, H., Sheu, L., Tibell, A. \& Bartfai, T. (2006). Impaired gene and protein expression of exocytotic soluble N-ethylmaleimide attachment protein receptor complex proteins in pancreatic islets of type 2 diabetic patients. Diabetes, Vol. 55, No.2 (February 2006), pp.435-440, 0012-1797

Oztan, A., Silvis, M., Weisz, O. A., Bradbury, N. A., Hsu, S. C., Goldenring, J. R., Yeaman, C. \& Apodaca, G. (2007). Exocyst requirement for endocytic traffic directed toward the 
apical and basolateral poles of polarized MDCK cells. Molecular biology of the cell, Vol. 18, No.10 (October 2007), pp.3978-3992, 1059-1524

Pattingre, S., Tassa, A., Qu, X., Garuti, R., Liang, X. H., Mizushima, N., Packer, M., Schneider, M. D. \& Levine, B. (2005). Bcl-2 antiapoptotic proteins inhibit Beclin 1dependent autophagy. Cell, Vol. 122, No.6 (September 2005), pp.927-939, 0092-8674

Polson, H. E., de Lartigue, J., Rigden, D. J., Reedijk, M., Urbe, S., Clague, M. J. \& Tooze, S. A. (2010). Mammalian Atg18 (WIPI2) localizes to omegasome-anchored phagophores and positively regulates LC3 lipidation. Autophagy, Vol. 6, No.4 (May 2010), pp. 506-522, 1554-8627

Pommereit, D. \& Wouters, F. S. (2007). An NGF-induced Exo70-TC10 complex locally antagonises Cdc42-mediated activation of N-WASP to modulate neurite outgrowth. Journal of cell science, Vol. 120, No.15 (August 2007), pp.2694-2705, 00219533

Ravikumar, B., Moreau, K., Jahreiss, L., Puri, C. \& Rubinsztein, D. C. (2010). Plasma membrane contributes to the formation of pre-autophagosomal structures. Nature cell biology, Vol. 12, No.8 (August 2010), pp.747-757, 1465-7392

Razi, M., Chan, E. Y. \& Tooze, S. A. (2009). Early endosomes and endosomal coatomer are required for autophagy. The Journal of cell biology, Vol. 185, No.2 (April 2009), pp.305-321, 0021-9525

Ren, M., Xu, G., Zeng, J., De Lemos-Chiarandini, C., Adesnik, M. \& Sabatini, D. D. (1998). Hydrolysis of GTP on Rab11 is required for the direct delivery of transferrin from the pericentriolar recycling compartment to the cell surface but not from sorting endosomes. Proceedings of the National Academy of Sciences of the United States of America, Vol. 95, No.11 (May 1998), pp.6187-6192, 0027-8424

Rioux, J. D. (2007). Genome-wide association study identifies new susceptibility loci for Crohn disease and implicates autophagy in disease pathogenesis. Nature genetics, Vol. 39, No.5 (May 2007), pp.596-604, 1061-4036

Rondaij, M. G., Bierings, R., van Agtmaal, E. L., Gijzen, K. A., Sellink, E., Kragt, A., Ferguson, S. S., Mertens, K., Hannah, M. J., van Mourik, J. A., Fernandez-Borja, M. \& Voorberg, J. (2008). Guanine exchange factor RalGDS mediates exocytosis of Weibel-Palade bodies from endothelial cells. Blood, Vol. 112, No.1 (July 2008), pp.56-63, 0006-4971

Rosse, C., Hatzoglou, A., Parrini, M. C., White, M. A., Chavrier, P. \& Camonis, J. (2006). RalB mobilizes the exocyst to drive cell migration. Molecular and cellular biology, Vol. 26, No.2 (January 2006), pp.727-734, 0270-7306

Saitoh, T., Fujita, N., Jang, M. H., Uematsu, S., Yang, B. G., Satoh, T., Omori, H., Noda, T., Yamamoto, N. \& Komatsu, M. (2008). Loss of the autophagy protein Atg16L1 enhances endotoxin-induced IL-1beta production. Nature, Vol. 456, No.7219 (November 2008), pp.264-268, 0028-0836

Sato, M. \& Sato, K. (2011). Degradation of paternal mitochondria by fertilization-triggered autophagy in C. elegans embryos. Science, Vol. 334, No.6059 (November 2011), pp.1141-1144, 0036-8075 
Savina, A., Fader, C. M., Damiani, M. T. \& Colombo, M. I. (2005). Rab11 promotes docking and fusion of multivesicular bodies in a calcium-dependent manner. Traffic, Vol. 6, No.2 (February 2005), pp.131-143, 1398-9219

Shandala, T., Woodcock, J. M., Ng, Y., Biggs, L., Skoulakis, E. M., Brooks, D. A. \& Lopez, A. F. (2011). Drosophila 14-3-3epsilon has a crucial role in anti-microbial peptide secretion and innate immunity. Journal of cell science, Vol. 124, No.13 (July 2011), pp.2165-2174, 0021-9533

Shin, S. W., Kim, S. Y. \& Park, J. W. (2011). Autophagy inhibition enhances ursolic acidinduced apoptosis in PC3 cells. Biochimica et biophysica acta, Vol. 1823, No.2 (December 2011), pp.451-457, 0006-3002

Shipitsin, M. \& Feig, L. A. (2004). RalA but not RalB enhances polarized delivery of membrane proteins to the basolateral surface of epithelial cells. Molecular and cellular biology, Vol. 24, No.13 (July 2004), pp.5746-5756, 0270-7306

Shorer, H., Amar, N., Meerson, A. \& Elazar, Z. (2005). Modulation of N-ethylmaleimidesensitive factor activity upon amino acid deprivation. The Journal of biological chemistry, Vol. 280, No.16 (April 2005), pp.16219-16226, 0021-9258

Shurety, W., Merino-Trigo, A., Brown, D., Hume, D. A. \& Stow, J. L. (2000). Localization and post-Golgi trafficking of tumor necrosis factor-alpha in macrophages. Journal of interferon $\mathcal{E}$ cytokine research, Vol. 20, No.4 (April 2000), pp.427-438, 1079-9907

Simonsen, A. \& Tooze, S. A. (2009). Coordination of membrane events during autophagy by multiple class III PI3-kinase complexes. Journal of cell biology, Vol. 186, No.6 (September 2009), pp.773-782, 0021-9525

Skinner, M. A. (2010). Membrane trafficking: Mapping a new route. Nature reviews. Molecular cell biology, Vol. 11, No.4 (April 2010), pp.234-235, 1471-0072

Spiczka, K. S. \& Yeaman, C. (2008). Ral-regulated interaction between Sec5 and paxillin targets Exocyst to focal complexes during cell migration. Journal of cell science, Vol. 121, No.17 (September 2008), pp.2880-2891, 0021-9533

Sramkova, M., Masedunskas, A., Parente, L., Molinolo, A. \& Weigert, R. (2009). Expression of plasmid DNA in the salivary gland epithelium: novel approaches to study dynamic cellular processes in live animals. American journal of physiology. Cell physiology, Vol. 297, No.6 (December 2009), pp.C1347-1357, 0363-6143

Stow, J. L., Manderson, A. P. \& Murray, R. Z. (2006). SNAREing immunity: the role of SNAREs in the immune system. Nature reviews. Immunology, Vol. 6, No.12 (December 2006), pp.919-929, 1474-1733

Stow, J. L., Low, P. C., Offenhauser, C. \& Sangermani, D. (2009). Cytokine secretion in macrophages and other cells: pathways and mediators. Immunobiology, Vol. 214, No.7 (July 2009), pp.601-612, 0171-2985

Sugihara, K., Asano, S., Tanaka, K., Iwamatsu, A., Okawa, K. \& Ohta, Y. (2002). The exocyst complex binds the small GTPase RalA to mediate filopodia formation. Nature cell biology, Vol. 4, No.1 (January 2002), pp.73-78, 1465-7392

Takaya, A., Kamio, T., Masuda, M., Mochizuki, N., Sawa, H., Sato, M., Nagashima, K., Mizutani, A., Matsuno, A., Kiyokawa, E. \& Matsuda, M. (2007). R-Ras regulates exocytosis by Rgl2/Rlf-mediated activation of RalA on endosomes. Molecular biology of the cell, Vol. 18, No.5 (May 2007), pp.1850-1860, 1059-1524 
Takeuchi, H., Furuta, N., Morisaki, I. \& Amano, A. (2011). Exit of intracellular Porphyromonas gingivalis from gingival epithelial cells is mediated by endocytic recycling pathway. Cellular microbiology, Vol. 13, No.5 (May 2011), pp.677-691, 1462-5814

Tanaka, Y., Guhde, G., Suter, A., Eskelinen, E. L., Hartmann, D., Lullmann-Rauch, R., Janssen, P. M., Blanz, J., von Figura, K. \& Saftig, P. (2000). Accumulation of autophagic vacuoles and cardiomyopathy in LAMP-2-deficient mice. Nature, Vol. 406, No.6798 (August 2000), pp.902-906, 0028-0836

Tanida, I., Minematsu-Ikeguchi, N., Ueno, T. \& Kominami, E. (2005). Lysosomal turnover, but not a cellular level, of endogenous LC3 is a marker for autophagy. Autophagy, Vol. 1, No.2 (July 2005), pp.84-91, 1554-8627

Tappel, A. (2005). Lysosomal and prostasomal hydrolytic enzymes and redox processes and initiation of prostate cancer. Medical hypotheses, Vol. 64, No.6 (February 2005), pp.1170-1172, 0306-9877

Tayeb, M. A., Skalski, M., Cha, M. C., Kean, M. J., Scaife, M. \& Coppolino, M. G. (2005). Inhibition of SNARE-mediated membrane traffic impairs cell migration. Experimental cell research, Vol. 305, No.1 (April 2005), pp.63-73, 0014-4827

TerBush, D. R., Maurice, T., Roth, D. \& Novick, P. (1996). The Exocyst is a multiprotein complex required for exocytosis in Saccharomyces cerevisiae. The EMBO journal, Vol. 15, No.23 (December 1996), pp.6483-6494, 0261-4189

Tooze, S. A. \& Razi, M. (2009). The essential role of early endosomes in autophagy is revealed by loss of COPI function. Autophagy, Vol. 5, No.6 (August 2009), pp.874$875,1554-8627$

Tooze, S. A. \& Yoshimori, T. (2010). The origin of the autophagosomal membrane. Nature cell biology, Vol. 12, No.9 (September 2010), pp.831-835, 1465-7392

Tra, T., Gong, L., Kao, L. P., Li, X. L., Grandela, C., Devenish, R. J., Wolvetang, E. \& Prescott, M. (2011). Autophagy in human embryonic stem cells. PloS one, Vol. 6, No.11 (November 2011), pp.e27485, 1932-6203

van Ijzendoorn, S. C. (2006). Recycling endosomes. Journal of cell science, Vol. 119, No.9 (May 2006), pp.1679-1681, 0021-9533

Varadi, A., Ainscow, E. K., Allan, V. J. \& Rutter, G. A. (2002). Involvement of conventional kinesin in glucose-stimulated secretory granule movements and exocytosis in clonal pancreatic $\beta$-cells. Journal of cell science, Vol. 115, No.21 (Nov 2002), pp.41774189, 0021-9533

Wang, A. L., Lukas, T. J., Yuan, M., Du, N., Tso, M. O. \& Neufeld, A. H. (2009). Autophagy and exosomes in the aged retinal pigment epithelium: possible relevance to drusen formation and age-related macular degeneration. PloS one, Vol. 4, No.1 (January 2009) pp.e4160, 1932-6203

Wang, C., Wang, Y., McNutt, M. A. \& Zhu, W. G. (2011). Autophagy process is associated with anti-neoplastic function. Acta biochimica et biophysica Sinica, Vol. 43, No.6 (June 2011), pp.425-432, 1672-9145

Wang, C. C., Ng, C. P., Lu, L., Atlashkin, V., Zhang, W., Seet, L. F. \& Hong, W. (2004). A role of VAMP8/endobrevin in regulated exocytosis of pancreatic acinar cells. Developmental cell, Vol. 7, No.3 (September 2004), pp.359-371, 1534-5807 
Wang, T., Ming, Z., Xiaochun, W. \& Hong, W. (2011). Rab7: role of its protein interaction cascades in endo-lysosomal traffic. Cellular signalling, Vol. 23, No.3 (March 2011), pp.516-521, 0898-6568

Ward, E. S., Martinez, C., Vaccaro, C., Zhou, J., Tang, Q. \& Ober, R. J. (2005). From sorting endosomes to exocytosis: association of Rab4 and Rab11 GTPases with the FC receptor, FcRn, during recycling. Molecular biology of the cell, Vol. 16, No.4 (April 2005), pp.2028-2038, 1059-1524

Webber, J. L., Young, A. R. \& Tooze, S. A. (2007). Atg9 trafficking in mammalian cells. Autophagy, Vol. 3, No.1 (January 2007), pp.54-56, 1554-8627

Webber, J. L. \& Tooze, S. A. (2010). New insights into the function of Atg9. FEBS letters, Vol. 584, No.7 (April 2010), pp.1319-1326, 0014-5793

Wei, Y. \& Zheng, X. F. (2011). Nutritional control of cell growth via TOR signaling in budding yeast. Methods in molecular biology, Vol. 759, No.2 (January 2011), pp.307319, 1064-3745

Weidberg, H., Shvets, E. \& Elazar, Z. (2011). Biogenesis and cargo selectivity of autophagosomes. Annual review of biochemistry, Vol. 80, (June 2011), pp.125-156, 0066-4154

Wiederkehr, A., De Craene, J. O., Ferro-Novick, S. \& Novick, P. (2004). Functional specialization within a vesicle tethering complex. The Journal of cell biology, Vol. 167, No.5 (December 2004), pp.875-887, 0021-9525

Wu, S., Mehta, S. Q., Pichaud, F., Bellen, H. J. \& Quiocho, F. A. (2005). Sec15 interacts with Rab11 via a novel domain and affects Rab11 localization in vivo. Nature structural $\mathcal{E}$ molecular biology, Vol. 12, No.10 (October 2005), pp.879-885, 1545-9985

Wurster, S., Nakov, R., Allgaier, C. \& Hertting, G. (1990). Involvement of N-ethylmaleimidesensitive $G$ proteins in the modulation of evoked $[(3) H]$ noradrenaline release from rabbit hippocampus synaptosomes. Neurochemistry international, Vol. 17, No.2 (January 1990), pp.149-155, 0197-0186

Yang, C., Mora, S., Ryder, J. W., Coker, K. J., Hansen, P., Allen, L. A. \& Pessin, J. E. (2001). VAMP3 null mice display normal constitutive, insulin- and exercise-regulated vesicle trafficking. Molecular and cellular biology, Vol. 21, No.5 (March 2001), pp.1573-1580, 0270-7306

Yu, W. H., Cuervo, A. M., Kumar, A., Peterhoff, C. M., Schmidt, S. D., Lee, J. H., Mohan, P. S., Mercken, M., Farmery, M. R., Tjernberg, L. O., Jiang, Y., Duff, K., Uchiyama, Y., Naslund, J., Mathews, P. M., Cataldo, A. M. \& Nixon, R. A. (2005). Macroautophagy--a novel Beta-amyloid peptide-generating pathway activated in Alzheimer's disease. The Journal of cell biology, Vol. 171, No.1 (October 2005), pp.8798, 0021-9525

Zajac, A., Sun, X., Zhang, J. \& Guo, W. (2005). Cyclical regulation of the exocyst and cell polarity determinants for polarized cell growth. Molecular biology of the cell, Vol. 16, No.3 (March 2005), pp.1500-1512, 1059-1524

Zeng, R., Chen, Y., Zhao, S. \& Cui, G. H. (2012). Autophagy counteracts apoptosis in human multiple myeloma cells exposed to oridonin in vitro via regulating intracellular ROS and SIRT1. Acta pharmacologica Sinica, Vol. 33, No.1 (January 2012), pp.91-100, 1671-4083 
Zhang, X., Wang, P., Gangar, A., Zhang, J., Brennwald, P., TerBush, D. \& Guo, W. (2005). Lethal giant larvae proteins interact with the exocyst complex and are involved in polarized exocytosis. The Journal of cell biology, Vol. 170, No.2 (July 2005), pp.273283, 0021-9525

Zhang, X. M., Ellis, S., Sriratana, A., Mitchell, C. A. \& Rowe, T. (2004). Sec15 is an effector for the Rab11 GTPase in mammalian cells. The Journal of biological chemistry, Vol. 279, No.41 (October 2004), pp.43027-43034, 0021-9258 


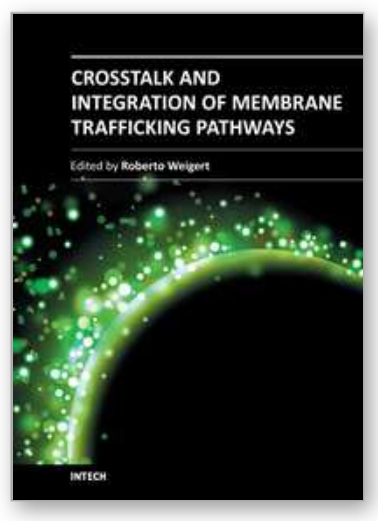

\author{
Crosstalk and Integration of Membrane Trafficking Pathways \\ Edited by Dr. Roberto Weigert
}

ISBN 978-953-51-0515-2

Hard cover, 246 pages

Publisher InTech

Published online 11, April, 2012

Published in print edition April, 2012

Membrane traffic is a broad field that studies the complex exchange of membranes that occurs inside the cell. Protein, lipids and other molecules traffic among intracellular organelles, and are delivered to, or transported from the cell surface by virtue of membranous carriers generally referred as "transport intermediates". These carriers have different shapes and sizes, and their biogenesis, modality of transport, and delivery to the final destination are regulated by a multitude of very complex molecular machineries. A concept that has clearly emerged in the last decade is that each membrane pathway does not represent a close system, but is fully integrated with all the other trafficking pathways. The aim of this book is to provide a general overview of the extent of this crosstalk.

\title{
How to reference
}

In order to correctly reference this scholarly work, feel free to copy and paste the following:

D.A. Brooks, C. Bader, Y.S. Ng, R.D. Brooks, G.N. Borlace and T. Shandala (2012). At the Intersection of the Pathways for Exocytosis and Autophagy, Crosstalk and Integration of Membrane Trafficking Pathways, Dr. Roberto Weigert (Ed.), ISBN: 978-953-51-0515-2, InTech, Available from: http://www.intechopen.com/books/crosstalk-and-integration-of-membrane-trafficking-pathways/at-theintersection-of-the-pathways-for-exocytosis-and-autophagy

\section{INTECH}

open science | open minds

\author{
InTech Europe \\ University Campus STeP Ri \\ Slavka Krautzeka 83/A \\ 51000 Rijeka, Croatia \\ Phone: +385 (51) 770447 \\ Fax: +385 (51) 686166 \\ www.intechopen.com
}

\author{
InTech China \\ Unit 405, Office Block, Hotel Equatorial Shanghai \\ No.65, Yan An Road (West), Shanghai, 200040, China \\ 中国上海市延安西路65号上海国际贵都大饭店办公楼 405 单元 \\ Phone: +86-21-62489820 \\ Fax: +86-21-62489821
}


(C) 2012 The Author(s). Licensee IntechOpen. This is an open access article distributed under the terms of the Creative Commons Attribution 3.0 License, which permits unrestricted use, distribution, and reproduction in any medium, provided the original work is properly cited. 